\title{
Erratum to: Bioaccumulation of polychlorinated biphenyls in juvenile chinook salmon (Oncorhynchus tshawytscha) outmigrating through a contaminated urban estuary: dynamics and application
}

\author{
James P. Meador • Gina M. Ylitalo • \\ Frank C. Sommers $\cdot$ Daryle T. Boyd
}

Published online: 24 November 2011

(C) Springer Science+Business Media, LLC 2011

Erratum to: Ecotoxicology (2010) 19:141-152,

DOI 10.1007/s10646-009-0399-x

In the original publication, the equation in the last sentence of Fig. 4 caption was published incorrectly. The correct version of the caption is given below.

Regression of total PCBs and PCB TEQs. Values are $\log _{10}$ total PCB concentrations in whole body juvenile chinook salmon and the sum of toxic equivalent quotients (TEQs) for the dioxin like PCBs. Arithmetic equivalents shown on the upper $x$-axis and right $y$-axis. The equation is $\Sigma$ TEQ $=-3.39+1.03 *$ tPCBs, all concentrations as $\log _{10}$ values (ng/g lipid or pg/g lipid).

The online version of the original article can be found under doi: 10.1007/s10646-009-0399-x.

J. P. Meador $(\bowtie)$. F. C. Sommers

Ecotoxicology and Environmental Fish Health Program, Environmental Conservation Division, Northwest Fisheries Science Center, National Marine Fisheries Service, NOAA, 2725, Montlake Boulevard East, Seattle, WA 98112, USA e-mail: James.meador@noaa.gov

G. M. Ylitalo · D. T. Boyd Environmental Assessment Program, Environmental Conservation Division, Northwest Fisheries Science Center, National Marine Fisheries Service, NOAA, 2725 Montlake Boulevard East, Seattle, WA 98112, USA 